OPEN ACCESS

Citation: Marco Cedeño-Fonseca, Orlando O. Ortiz, Alejandro Zuluaga, Michael H. Grayum, Thomas B. Croat (2021) Four new species of Monstera (Araceae) from Panama, including one with the largest leaves and another with the largest inflorescences in the genus. Webbia. Journal of Plant Taxonomy and Geography 76(2): 265-279. doi: 10.36253/jopt-10807

Received: April 19, 2021

Accepted: July 27, 2021

Published: September 7, 2021

Copyright:@2021 Marco Cedeño-Fonseca, Orlando O. Ortiz, Alejandro Zuluaga, Michael H. Grayum, Thomas B. Croat. This is an open access, peerreviewed article published by Firenze University Press (http://www.fupress. $\mathrm{com} /$ webbia) and distributed under the terms of the Creative Commons Attribution License, which permits unrestricted use, distribution, and reproduction in any medium, provided the original author and source are credited.

Data Availability Statement: All relevant data are within the paper and its Supporting Information files.

Competing Interests: The Author(s) declare(s) no conflict of interest.

Editor: Riccardo M. Baldini

ORCID

MCF: https://orcid.org/0000-0003-01190427

O०O: https://orcid.org/0000-00027805-0046

AZ: https://orcid.org/0000-0002-58746353

MHG: https://orcid.org/0000-00029501-1161

TBC: https://orcid.org/0000-0001-68100567

\section{Four new species of Monstera (Araceae) from Panama, including one with the largest leaves and another with the largest inflorescences in the genus}

\author{
Marco Cedeño-Fonseca ${ }^{1}$, Orlando O. Ortiz ${ }^{2,3}$, Alejandro Zuluaga ${ }^{4}$, \\ Michael H. Grayum ${ }^{5}$, Thomas B. Croat ${ }^{5}$ \\ ${ }^{1}$ Herbario Luis Fournier Origgi (USJ), Universidad de Costa Rica, San José, Costa Rica. \\ ${ }^{2}$ Departamento de Botánica \& Herbario PMA, Universidad de Panamá, Estafeta Univer- \\ sitaria, Panama City, Panama. \\ ${ }^{3}$ Coiba Scientific Station (COIBA AIP), Clayton, Panama City, Panama. \\ ${ }^{4}$ Departamento de Biología, Universidad del Valle, Calle 13, \#100-00, Cali, Colombia. \\ ${ }^{5}$ Missouri Botanical Garden, 4344 Shaw Blvd., St. Louis, Missouri 63110, U.SA. \\ ${ }^{*}$ Corresponding author. E-mail: marcovf.09@gmail.com
}

\begin{abstract}
Monstera bocatorensis Croat \& M.Cedeño, Monstera donosoensis Croat, M.Cedeño \& O.Ortiz, Monstera gigas Croat, Zuluaga, M.Cedeño \& O.Ortiz, and Monstera titanum Croat, M.Cedeño \& O.Ortiz are newly described from Panama, and illustrated from living material.
\end{abstract}

Keywords: Araceae, Central America, Monstera, Panama, Parque Internacional de La Amistad, Talamanca, taxonomy.

\section{INTRODUCTION}

Monstera Adanson (1763), widespread in the Neotropics, is especially diverse in the Cordillera de Talamanca of Costa Rica and Panama (Madison 1977), principally on the Caribbean slope (Cedeño-Fonseca 2019). This genus, composed of nomadic vines (Sperotto et al. 2020), belongs to Araceae subfamily Monsteroideae, and is the only Neotropical genus of the pantropical tribe Monstereae, or Rhaphidophora clade (Tam et al., 2004; Zuluaga et al. 2019). Despite a relatively recent revision (Madison, 1977), Monstera is taxonomically the most poorly understood genus of Araceae in the Neotropics (Grayum 2003). The morphological features manifest on herbarium specimens are often inadequate for characterization and identification, due to the large size of the plants and their extreme intraspecific variation (Grayum 2003).

Madison (1977) believed that Panama had the highest diversity of Monstera species, but recent studies (e.g., Cedeño-Fonseca et al. 2018, 2020a, 2020b, 2020c, 2020d, 2020e) have elevated Costa Rica, with 32 accepted species of Monstera, to first place in this category. However, field work in 
Panama during 2016-2019, as part of an ongoing revision of Monstera for the Mesoamerican region (Croat et al., in prep.), has revealed the four new species here described, raising the Panamanian total for the genus to 29 species. All of these new species belong to Monstera section Monstera (sensu Madison, 1977: 90), characterized by seedlings with foliose leaves - unlike the stoloniferous sections Echinospadix Madison (1977) and Marcgraviopsis Madison (1977), and the juvenile stage with the leaves not appressed ('shingling') to the phorophyte (host tree).

\section{MATERIALS AND METHODS}

The first and second author carried out field exploration in Panama between 2016 and 2021 and studied Monstera collections deposited at the following herbaria: CR, HLDG, JVR, LSCR, MEXU, MO, NY, PMA, SEL, $\mathrm{UCH}$, and USJ. Herbarium acronyms cited above and elsewhere in this paper follow Thiers (2021). Three of the four species described here are illustrated with photographic plates showing different parts of the plants in life, adapted from the "Lankester Composite Dissection Plate" technique proposed for Orchidaceae at Lankester Botanical Garden, Universidad de Costa Rica (Pupulin and Bogarín 2004). Due to the high demand for species of the genus Monstera as ornamental plants, and a rapidly growing black market that endangers native populations (even in protected areas), coordinates are here omitted from all specimen citations.

\section{TAXONOMIC TREATMENT}

Monstera bocatorensis Croat \& M.Cedeño, sp. nov. (Figures 1, 2)

Type: Panama. Bocas del Toro: Along road between Chiriquí Grande and Fortuna, $7.7 \mathrm{mi} \mathrm{W}$ of Chiriquí Grande, $1.5 \mathrm{mi} \mathrm{W}$ of Punta Peña, disturbed primary forest, 80 m, 9 Mar 1985, T.Croat \& M.Grayum 60088 (holotype: MO-3123561!; isotypes, B, COL, K, NY, PMA!, US).

\section{Diagnosis}

Monstera bocatorensis is characterized by its smooth and glaucous stems, long, smooth petioles glaucous throughout and $46-90 \mathrm{~cm}$ long, short petiole sheaths that extend only to the middle or $3 / 4$ of its length, usually deeply pinnatifid (rarely entire) leafblades, never perforate, and smooth, light green or dark green peduncles, $27-45 \mathrm{~cm}$ long, entirely covered by the cataphylls.

\section{Description}

Habit: Robust nomadic vine, appressed-climbing. Seedlings: bearing foliose leaves. Juvenile plants: root climbers; stems completely terrestrial or ascending, dark green, smooth and glaucous, cylindrical; internodes $0.5-4 \mathrm{~cm}$ long, $0.5-1 \mathrm{~cm}$ diam.; petiole dark or light green, smooth and glaucous at the base, $8-20 \mathrm{~cm}$ long, sheathed for 3-7 cm, or up to the middle; petiole sheath persistent and involute; unsheathed portion terete; leaf-blades ovate to elliptic-ovate, attenuate at the base, acuminate at apex, thinly coriaceous, 10-25 $\times 6-10 \mathrm{~cm}$, not appressed to the phorophyte; fenestrations absent or present (usually one fenestrated side which breaks at the margin). Adult plants: root climbers; stems dark green or shiny beige, cylindrical and slightly flattened; internodes $1-2.5 \mathrm{~cm}$ long, $1.5-3 \mathrm{~cm}$ diam.; cataphylls with a very small blade at the apex, persistent, light green to pruinose; anchor roots light brown, with root trichomes; feeder roots light brown, with root trichomes; petiole light green or dark green, smooth and glaucous throughout, 46-90 cm long, sheathed up to the middle or $5-15 \mathrm{~cm}$ beyond the middle; petiole sheath persistent and involute; unsheathed portion terete and slightly ribbed near the geniculum; geniculum sunken adaxially and convex abaxially, 2-3.5 cm long; leaf-blades ovate to oblong-ovate, rounded at the base, short-acuminate at apex, subcoriaceous, (31-)48-58 x (13.5-)20-32 cm, 1.7-2.0(-2.6) times longer than wide, not decurrent on the geniculum; midrib ribbed adaxially, convex abaxially; primary lateral veins $14-20$ per side, departing midrib at $60-90^{\circ}$, strongly sunken adaxially, prominent abaxially; secondary veins completely parallel; collective veins scarcely visible on the margins of each lobe; fenestrations absent; margins deeply pinnatifid or (rarely) entire, generally with 2-6 lobes per side, $3-20 \mathrm{~cm}$ wide, with 3-10 veins per lobe. Inflorescences on ascending stems, 1 or 2 simultaneously in flowering season; peduncle smooth, light green or dark green, 27-45 $\mathrm{cm}$ long, $1 \mathrm{~cm}$ diam., entirely covered by cataphylls; spathe acuminate, membranous, completely open, with margins overlapping at the base, light green during development, creamy or white externally and white with longitudinal greenish or white veins internally at anthesis, $12-17 \times 5-9 \mathrm{~cm}$, up to $6 \mathrm{~cm}$ longer than the spadix; spadix white during development and at anthesis, $11-12 \mathrm{~cm}$ long, $1.7-2.2 \mathrm{~cm}$ diam.; basal sterile flowers 3-5 $\mathrm{mm}$ long, globose and with a very prominent stigmatophore and an orange stigmatic secre- 


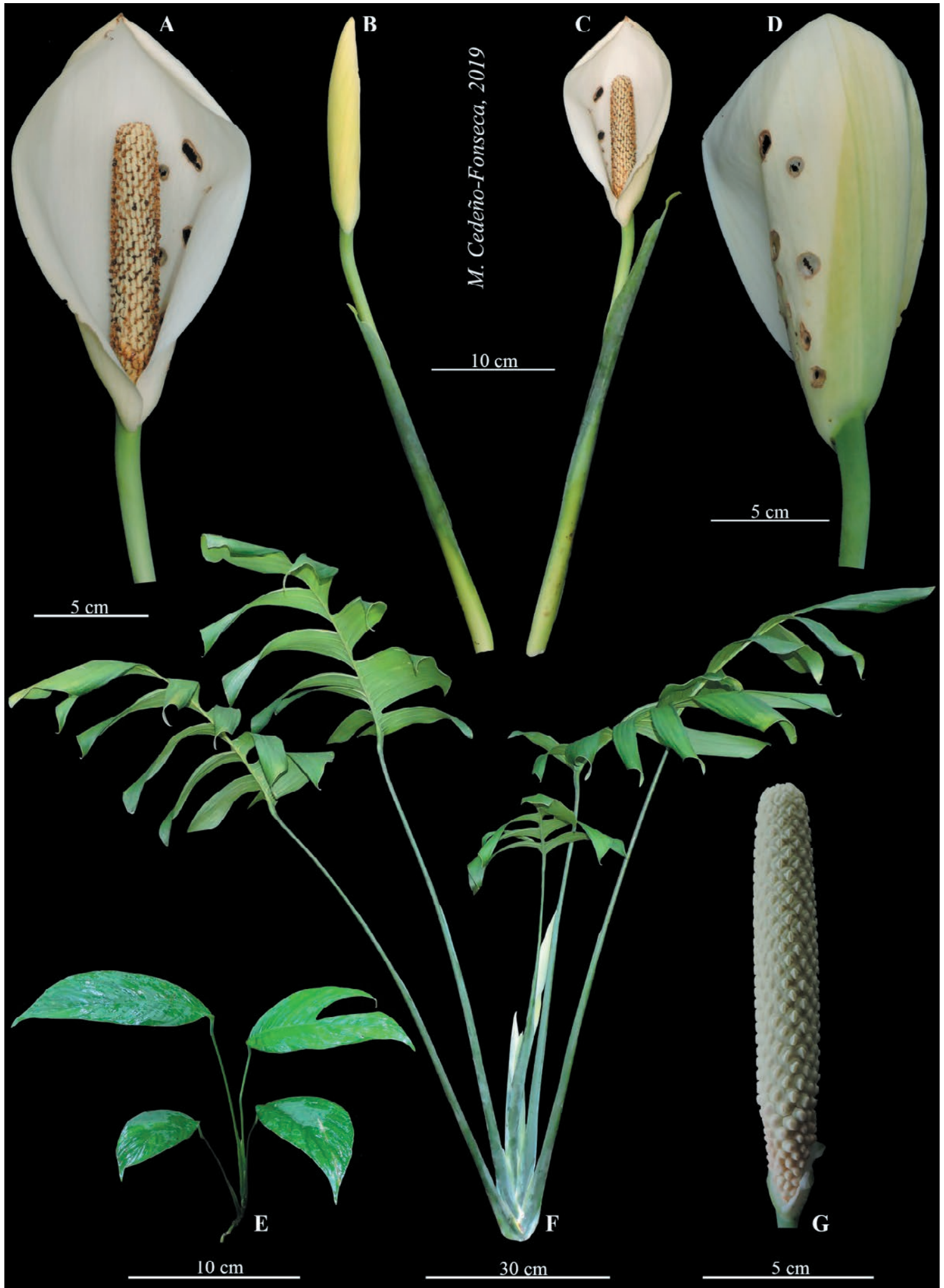

Figure 1. Monstera bocatorensis. A. Front view of open inflorescence. B. Developing inflorescence. C. Front view of open inflorescence with peduncle and persistent cataphyll. D. Back view of open inflorescence. E. Juvenile plant. F. Adult plant. G. View of spadix at female anthesis, showing flowers with stigmatophore lateral-flattened. Photos by Marco Cedeño-Fonseca. 

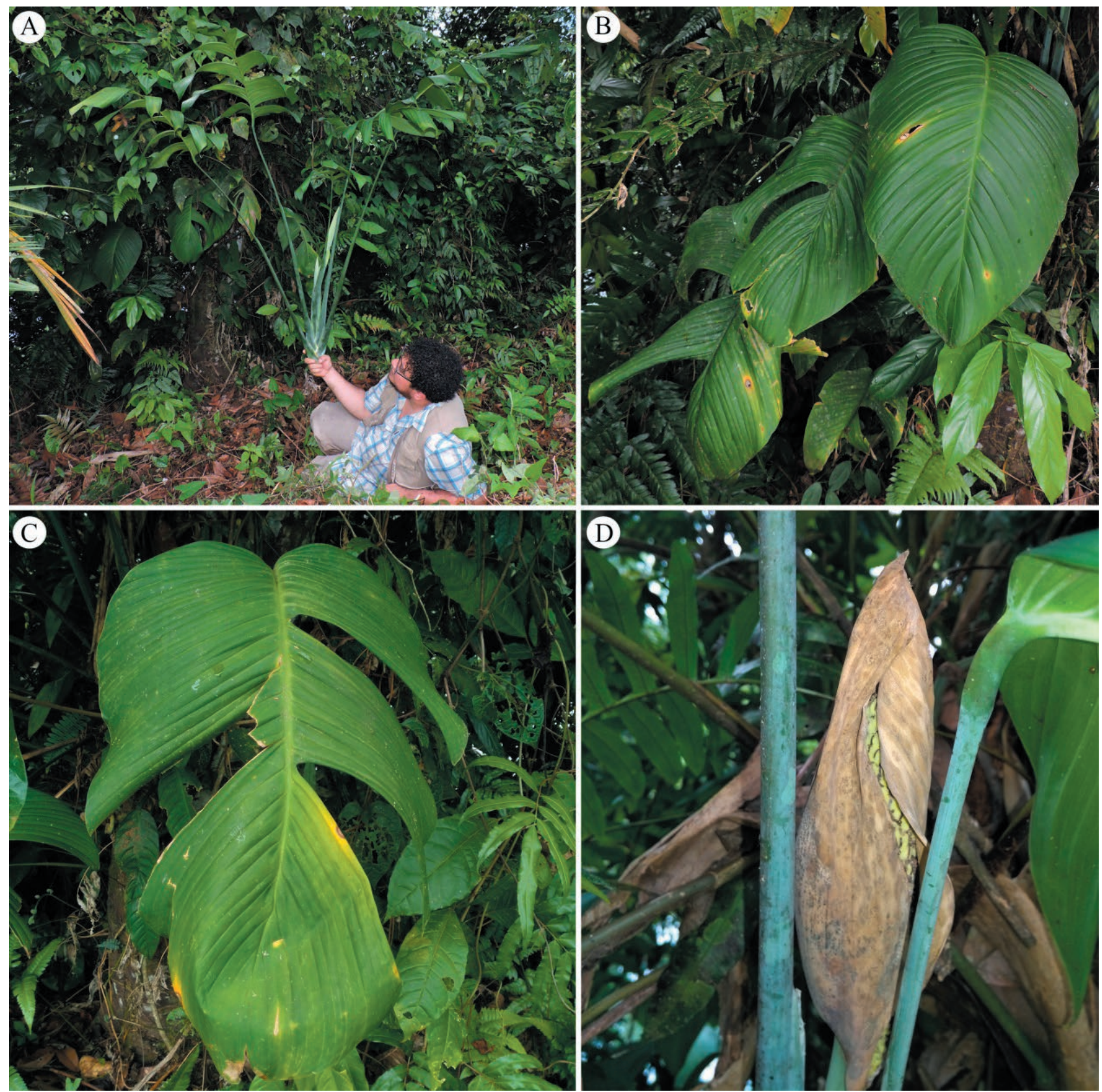

Figure 2. Monstera bocatorensis. A. Adult plant, leaf-blades with 4-6 lobes per side. B. Adult plant, one leaf-blade entire and one with 2 or 3 lobes per side. C. Adult plant, leaf-blade with 2 or 3 lobes per side. D. Spathe, marcescent after male anthesis and enclosing the spadix. Photos by Marco Cedeño-Fonseca.

tion; fertile flowers 5-6 mm long; stamens with laminar filaments $1.5-5 \mathrm{~mm}$ long; anthers $1-2 \mathrm{~mm}$ long; ovary quadrangular in longitudinal section, $1.5-2.5 \times$ $1.5-2 \mathrm{~mm}$; style quadrangular, cylindrical, or hexagonal, $0.5-1 \times 2-3 \mathrm{~mm}$; stigmatophore columnar, slightly ribbed on style, $0.5-1 \mathrm{~mm}$ long; stigma linear with a transparent stigmatic secretion; berries with green sty- lar cap during development, unknown when ripe; pulp unknown; seeds unknown.

\section{Etymology}

The species is named after Bocas del Toro Province, Panama, where all the known specimens have been collected. 


\section{Distribution and habitat}

Monstera bocatorensis is endemic to Panama, where it is known only from the western slopes of the mountains east of Fortuna Dam below the Continental Divide in Bocas del Toro Province, from sea level to $1100 \mathrm{~m}$, in the Tropical wet forest and Premontane wet forest life zones.

Phenology

Fruiting has been recorded in March and June.

\section{Conservation status}

Monstera bocatorensis should be considered as data deficient (DD), because we lack adequate geographic distribution and population information to make an assessment based on the IUCN criteria (IUCN Standards and Petitions Subcommittee 2017; IUCN 2019).

\section{Notes}

This species is characterized by its ovate, yellowishdrying leaf-blades that are never perforate, frequently pinnatifid with two or three very unequal pinnae, or rarely entire. Other characteristic features are the short petiole sheaths that extend only to the middle or $3 / 4$ of its length, as well as the glaucous petioles and blades. This species is similar to M. glaucescens Croat \& Grayum (Grayum 1997), but differs from that species by its leaf-blades drying light yellow-brown on the lower surface and with having the pinnae markedly unequal. In contrast, the leaves of $M$. glaucescens have blades that dry dark brown and have much narrower pinnae, with more long-tapered and more prominently falcate pointed lobes. Another species with which it could be confused is Monstera croatii M.Cedeño \& A.Hay (in Cedeño et al., 2020c), but that species differs by its deeply pinnatifid and bluish green leaf blades, with bifid lobes, a persistent sheathing mucronate cataphyll, and spathe with two longitudinal keels.

\section{Additional specimens examined (paratypes):}

PANAMA. Bocas del Toro, Laguna de Chiriquí, rincón SE. Nuri: campamento cerca población Guaymi. $15 \mathrm{~km} \mathrm{~W}$ de Puntas Cricamola, entrando Ensenada de Catavela, y subiendo Quebrada Nuri, 10-25 m, Foster et al. 14604 (MO); Fortuna, La Fortuna area to Chiriquí Grande and the oil pipeline; along dirt road $10 \mathrm{mi}$ from continental divide, just past 2 nd large bridge; $1 \mathrm{mi}$ north from highway, 130 m, Hammel et al. 14599 (MO); Chiriquí Grande, Rembala, Vicinity of Chiriquí Grande, near town of Rembala [Rambala], on trail west of road, $250 \mathrm{~m}$, McPherson et al. 11150 (MO).
Monstera donosoensis Croat, M.Cedeño \& O.Ortíz, sp. nov. (Figures 3, 4)

Type: Panama. Colón: Donoso District. Minera Panamá copper-mining concession, slopes and ridges in drainage of Quebrada Brazo, 243 m, 30 Aug 2014, M.Grayum, G.McPherson, C.Ramos, I.Vergara-Pérez \& L.Rojas 13242 (holotype, PMA!; isotype, MO-6636330!).

\section{Diagnosis}

Monstera donosoensis is characterized by its dark green petioles with a deciduous or slightly persistent sheath, entire, pinnatilobed, or scarcely pinnatifid leaf blades, with or without fenestrations, spathe yellowish or cream externally and white or creamy internally, and flowers with the style hexagonal, strongly conical, and distally cylindrical.

\section{Description}

Habit: robust nomadic vine, appressed-climbing. Seedlings: bearing foliose leaves. Juvenile plants: root climbers; stems light green or beige, sometimes whitedotted, smooth, cylindrical; internodes $2-5 \mathrm{~cm}$ long, 0.5-1 cm diam.; petiole distinct, light green, smooth, $8-15 \mathrm{~cm}$ long, sheathed to the base of the geniculum; petiole sheath deciduous or slightly persistent; leafblades ovate to lanceolate, attenuate or cuneate at the base, the tip acuminate, subcoriaceous to coriaceous, 10-25 $\times 9-15 \mathrm{~cm}$, not appressed to the phorophyte; fenestrations absent or present, only in one side of the lamina. Adult plants: root climbers; stems beige to light brown, smooth, cylindrical; internodes $1-4 \mathrm{~cm}$ long, 1-5 cm diam.; anchor roots light brown or beige; feeder roots corky, dark brown; petiole dark green, scarcely white-dotted, smooth, $22-41.5 \mathrm{~cm}$ long, fully sheathed, or for up to $15 \mathrm{~cm}$; petiole sheath deciduous or slightly persistent, horizontally open; geniculum smooth, sunken adaxially, convex abaxially, $0.5-3 \mathrm{~cm}$ long; blades ovate to elliptic, rounded or truncate at the base, subcoriaceous to coriaceous, obtuse to short-acuminate at apex, drying glossy, beige or brownish, 26.5-47 $\times 16.3-25$ $\mathrm{cm}, 1.62-1.88$ times longer than wide, decurrent on the geniculum, decurrent portion 1-2 mm wide; midrib ribbed adaxially, convex abaxially, drying light or reddish brown on both surfaces, primary lateral veins 6-20 per side, strongly sunken adaxially, prominent abaxially, departing the midrib at $50-60^{\circ}$, drying brownish or reddish; secondary veins prominent and parallel, reticulate toward the margin; collective veins slightly visible toward lobes; fenestrations absent or present; margins entire, pinnatilobed or scarcely pinnatifid, with 2-8 lobes per side. Inflorescences: on ascending stems; 


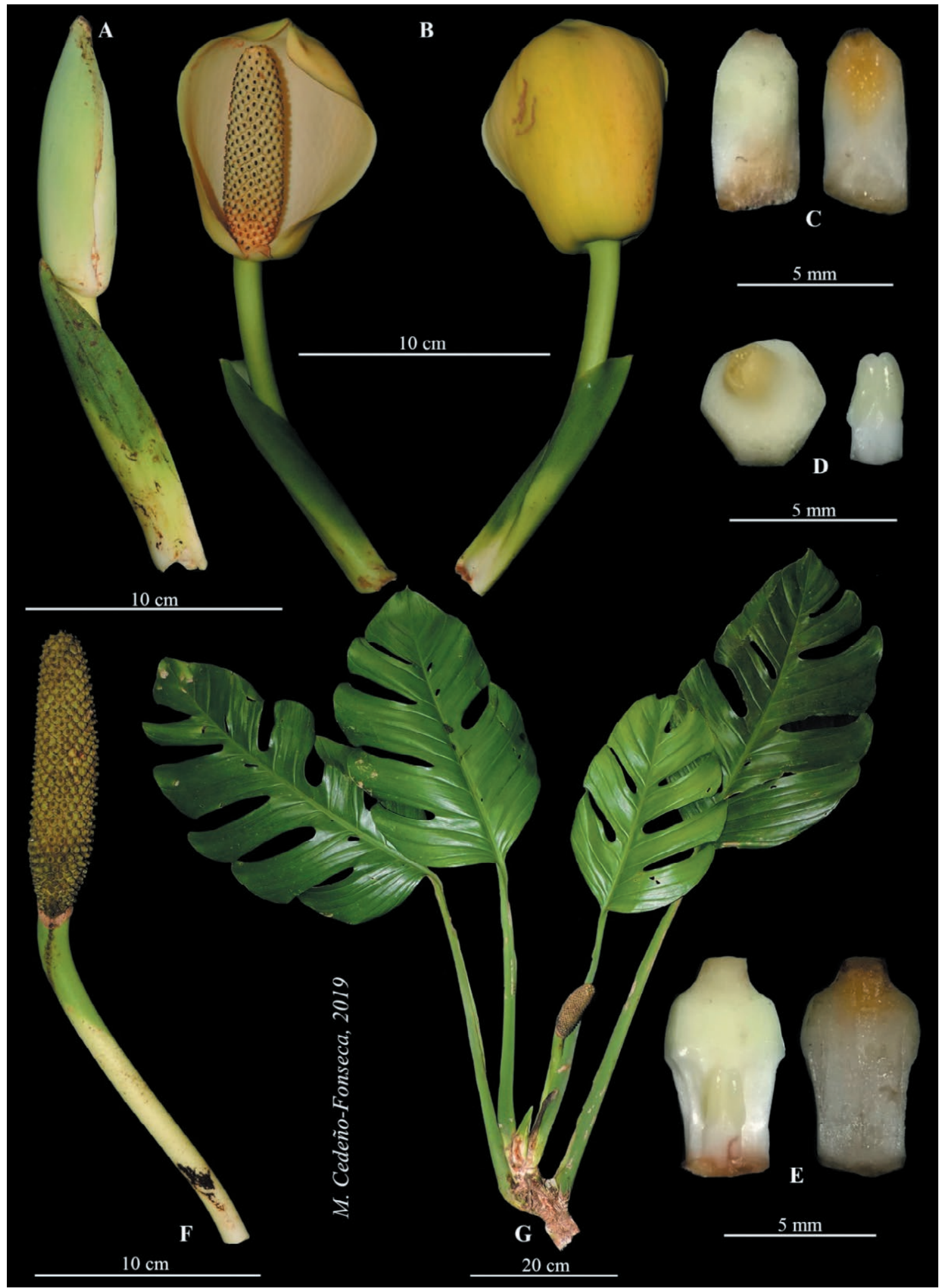

Figure 3. Monstera donosoensis. A. Developing inflorescence. B. Front and back views of open inflorescence. C. Sterile flower in lateral view (left) and longitudinal section (right). D. Stylar plate, top view (left), and individual stamen (right). E. Fertile flower in lateral view (left) and longitudinal section (right). F. Immature infructescence. G. Adult plant. Photos by Marco Cedeño-Fonseca. 


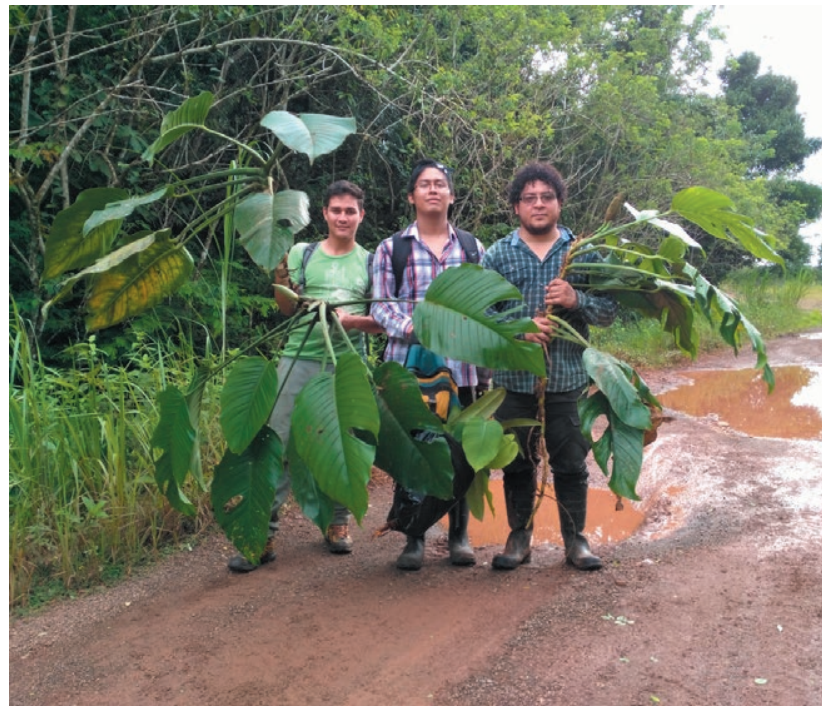

Figure 4. Different adult plants of $M$. donosoensis recollected in Santa Rita, Colón, Province, Panama, showing entire, pinnatilobed, and scarcely pinnatifid (with 2-4 lobes per side) leaf-blades. Photo by Riccardo M. Baldini (Tropical herbarium FT, University of Firenze, Italy)..

peduncle smooth, $11.5-19 \mathrm{~cm}$ long; spathe obtuse to short-acuminate, light green during development, yellowish or cream externally and white or creamy internally at anthesis, completely open, marcescent after anthesis, $10-20 \times 6-10 \mathrm{~cm}$, up to $2 \mathrm{~cm}$ longer than the spadix; spadix white or cream (both during development and at anthesis), $9-10.5 \mathrm{~cm}$ long, $1.8-2.5 \mathrm{~cm}$ diam., 4.1-4.2× longer than wide; basal sterile flowers $4-6 \mathrm{~mm}$ long, with an orange stigmatic secretion; fertile flowers 5-9 mm long; stamens with laminar filaments 2-6.5 $\mathrm{mm}$ long; anthers 1.3-2 mm long; ovary rectangular in longitudinal section, ribbed, $3-4 \times 1.5-2.5 \mathrm{~mm}$; style hexagonal and strongly conical, distally cylindrical, $2-5$ $\times 2-3 \mathrm{~mm}$; stigma circular, with an orange stigmatic secretion; berries with a light or dark green stylar cap during development, mature stylar cap cream-yellowish; pulp unknown; seeds unknown.

\section{Etymology}

The species is named after Donoso District, Colón Province, Panama, in which the type was collected.

\section{Distribution and habitat}

Monstera donosoensis is endemic to Panama, where it is known from Darién, Coclé, Colón, Veraguas, Panamá, Panamá Oeste provinces, and Guna Yala comarca, at elevations of $100-1600 \mathrm{~m}$, in the Premontane rainforest life zone.

\section{Phenology}

Flowering has been recorded in January, March, April, June, August, October, November, and December. Fruiting has been recorded in January, February, March, April, July, and October.

\section{Conservation status}

The distribution of this species includes at least 10 locations of which seven are in protected areas. It has an EOO of $29,214.84 \mathrm{~km}^{2}$ and an AOO of $104 \mathrm{~km}^{2}$, therefore, $M$. donosoensis could be assessed as Least Concern [LC].

\section{Notes}

This species is characterized by its thick stems, with moderately short internodes, long, nearly fully sheathed petioles, with the sheath deciduous or slightly persistent, and moderately coriaceous, dark brown-drying, usually sparsely perforate, ovate-elliptic, and weakly acuminate leaf-blades, inequilaterally subrounded to acute at the base, with the primary lateral veins heavily aggregated near the base and the fenestrations (when present) large and few, mostly beginning near the midrib, as well as by its long-pedunculate inflorescences with the spathe greenish, cream-colored within, and the spadix about $2 / 3$ as long as the spathe, and especially by its flowers with a protruding, hexagonal, strongly conical and distally cylindrical style. Monstera donosoensis is similar to M. dissecta (Schott) Croat \& Grayum (1987), but differs in having petioles speckled with white dots, with the sheath deciduous or slightly persistent, coriaceous leaf-blades, and flowers with a hexagonal, strongly conical, and distally cylindrical style. Monstera donosoensis has similar characteristics to the South American M. adansonii Schott subsp. klotzschiana (Schott) Mayo \& I.M.Andrade (2013), but the latter differs in having dark green, less frequently mottled petioles with the sheath persistent, and slightly coriaceous leaf-blades.

\section{Additional specimens examined (paratypes)}

PANAMA: Coclé, Road to Coclesito. Logging camp 12 miles from Llano Grande, $200 \mathrm{~m}$, Churchill et al. 3984 (MO); Along road past Furlong's Finca, due N of Cerro Pilón, 880 m, Croat 37573 (MO); On Atlantic slope near the Continental Divide along lumbering road $\mathrm{N}$ of El Cope, $9.4 \mathrm{~km}$ above El Cope (2.2 km N of lumber sawmill), 750-900 m, Croat 44750 (MO); Near continental divide along lumber road $5.2 \mathrm{mi} \mathrm{N}$ of El Cope, $1.5 \mathrm{mi} \mathrm{N}$ of lumber camp. Cloud forest on steep slopes, $900 \mathrm{~m}$, Croat 
44574 (MO); North of El Copé, 500 m, D’Arcy 11294 (MO); Foot of Cerro Pilón, above El Valle de Antón, Rain forest, $2000 \mathrm{ft}$, Porter et al. 4431 (MO); Trail between the Río Blanco and the Continental Divide north of El Cope and El Petroso sawmill, 400-1700 $\mathrm{ft}$, Sytsma et al. 2605 (MO); North rim of El Valle de Antón, near Cerro Turega, 650-700 m, Woodson \& Schery 185 (MO). Colón, Santa Rita Ridge Road, 4-6 km from Transisthmian Highway. Disturbed primary forest, $150-200 \mathrm{~m}$, Croat 34281 (MO); Santa Rita Arriba. Bosque secundario, orillas de la carretera, 380 m, Ortiz et al. 3452 (PMA, MO). Darién, Cerro Tacarcuna massif west ridge, vicinity of summit camp, lower montane wet forest, $1500-1600 \mathrm{~m}$, Gentry \& Mori 14161 (MO). Panamá, Chepo, El Llano-Cartí Road, 7-12 km from Interamerican Highway, 360-400 m, Croat 25155 (MO); Capira, Cerro Campana, along trail to Summit, 780-875 m, Croat 25194A (MO); Capira, Cerro Campana, along trail to summit, 780-875 m, Croat 25244 (MO); Cerro Jefe, $21 \mathrm{~km}$ above Pan-Am Highway, $600 \mathrm{~m}$, Croat 35890 (MO); Capira, Middle slopes of Cerro Campana, ca. 1 mile from Interamerican Highway, $150 \mathrm{~m}$, Croat 35990 (MO); Chepo, Road from El Llano to Cartí, $8.7 \mathrm{~km} \mathrm{~N}$ of the Panamerican Highway, 200-300 m, Folsom \& Small 6162 (MO); Near top of Cerro Jefe to 1 mile beyond, $900-1000 \mathrm{~m}$, Gentry 3499 (MO); Cerro Jefe, in forest alongside road north off of road to tower, $820 \mathrm{~m}$, Hammel \& McPherson 14534 (MO); Chepo, Along newly cut road from El Llano to Carti-Tupile; 12 miles above Pan-Am Highway, Primary forest, 200-500 m, Liesner 693 (MO); Capira, Summit of Cerro Campana, Rain forest, $3220 \mathrm{ft}$, Porter 4951 (MO); El Llano-Cartí Road, tropical moist forest, $12 \mathrm{~km}$ from Pan American Hwy, $1000 \mathrm{ft}$, Sytsma 1745 (MO); Chepo, $16-18 \mathrm{~km}$ from Interamerican Highway on the El Llano-Cartí Road, $400 \mathrm{~m}$, Tyson \& Nee 7356 (MO). San Blas, El Llano-Cartí Road, 350 $\mathrm{m}$, de Nevers \& Herrera 4356 (MO). Veraguas, Santa Fe, 5 miles W of Santa Fé on road past Escuela Agricola Alto Piedra on Pacific side of divide, 800-1200 $\mathrm{m}$, Croat 23053 (MO); 2/10 mile beyond fork in road at Escuela Agricola Alto Piedra on road to Rio Calovebora, 750 m, Croat \& Folsom 33969 (MO); "Cerro Tute" ridge up from former Escuela Agrícola, Santa Fé, moist forest, $800-1000 \mathrm{~m}$, Hamilton \& Dressler 3042 (MO); Santa Fe, Along steep trail to summit of Cerro Tute, ca. $3 \mathrm{~km}$ above Escuela Agricultura Alto Piedra near Santa Fé, 3000-3100 ft, Sytsma \& Antonio 3058 (MO). Coclé: Near sawmill $16.7 \mathrm{~km} \mathrm{~N}$ of turnoff to Coclesito from Llano Grande, $700 \mathrm{ft}$, Hammel 1836 (MO).
Monstera gigas Croat, Zuluaga, M.Cedeño \& O.Ortiz, sp. nov. (Figure 5, 6, 7)

Type: Panama. Chiriquí: Fortuna Dam area, unnamed creek to E of road flowing into Río Hornito near Quebrada Moro, 1200 m, 16 Jun 1984, W.Churchill 5508 (holotype, MO-3216379-821!; isotype, PMA!).

\section{Diagnosis}

Monstera gigas is characterized by petioles with white dots, a slightly persistent sheath, sometimes enormous leaf blades subcordate at the base, with entire margins, with or without fenestrations, and 24-65 primary lateral veins per side, sunken adaxially, departing the midrib at $80-90^{\circ}$ in the lower part of the blade and $55-75^{\circ}$ toward the apex.

\section{Description}

Habit: very robust to gigantic pachycaul appressedclimbing nomadic vine or rarely terrestrial. Seedlings: bearing foliose leaves. Juvenile plants: unknown. Adult plants: root climbers; stems pale green, smooth, cylindrical; internodes $1.5-2 \mathrm{~cm}$ long, 3-11 cm diam.; anchor roots unknown; feeder roots unknown; petiole light green, white-dotted, smooth, (45-)66-81(-140) cm long, sheathed up to (0.36-)0.74-0.86 its total length, 13-17 $\mathrm{cm}$; petiole sheath slightly persistent, drying dark brown with pale brown margins; geniculum white-dotted, 17 $\mathrm{cm}$ long, $3 \mathrm{~cm}$ diam.; leaf-blades narrowly ovate-elliptic, rounded on both sides, subcordate on one side and rounded on the other side, or unequal (one side $4-5 \mathrm{~cm}$ wider) at the base, short-acuminate at apex, moderately coriaceous, (43-)72-86(-140) $\times(25.6-) 34-40(-61) \mathrm{cm}$, 1.67-2.2 times longer than wide; fenestrations absent or present; margins entire; midrib weakly sunken adaxially to weakly discolored toward the distal margin, greenish white and thicker than broad abaxially, convex toward the apex, closely rounded and pale brown below; primary lateral veins (21-)24-65 per side, sunken adaxially, closely narrowly rounded and pale abaxially, departing the midrib at $\left(40^{\circ}-\right) 55-75^{\circ}$ toward the apex and $80-90^{\circ}$ in the lower part of the blade; secondary veins parallel, moderately prominent adaxially. Inflorescences on ascending stems; peduncle smooth, $34-38.5 \mathrm{~cm}$ long, $1.7-2.2 \mathrm{~cm}$ diam.; spathe acuminate, white at anthesis, coriaceous, $30-34 \times 15-18.5 \mathrm{~cm}$; spadix white at anthesis, $20-25.5 \mathrm{~cm}$ long, $3.2-4.2 \mathrm{~cm}$ diam.; basal sterile flowers 3-5 mm long; fertile flowers 5-6 $\mathrm{mm}$ long; stamens with laminar filaments; anthers $1.5-2 \mathrm{~mm}$ long; ovary rectangular in longitudinal section, ribbed, $4-5 \times 1.5-2.5 \mathrm{~mm}$; style hexagonal, 1.5-2 $\times 1.5-2 \mathrm{~mm}$; stigma circular; berries with a white stylar cap when ripe; seeds unknown. 

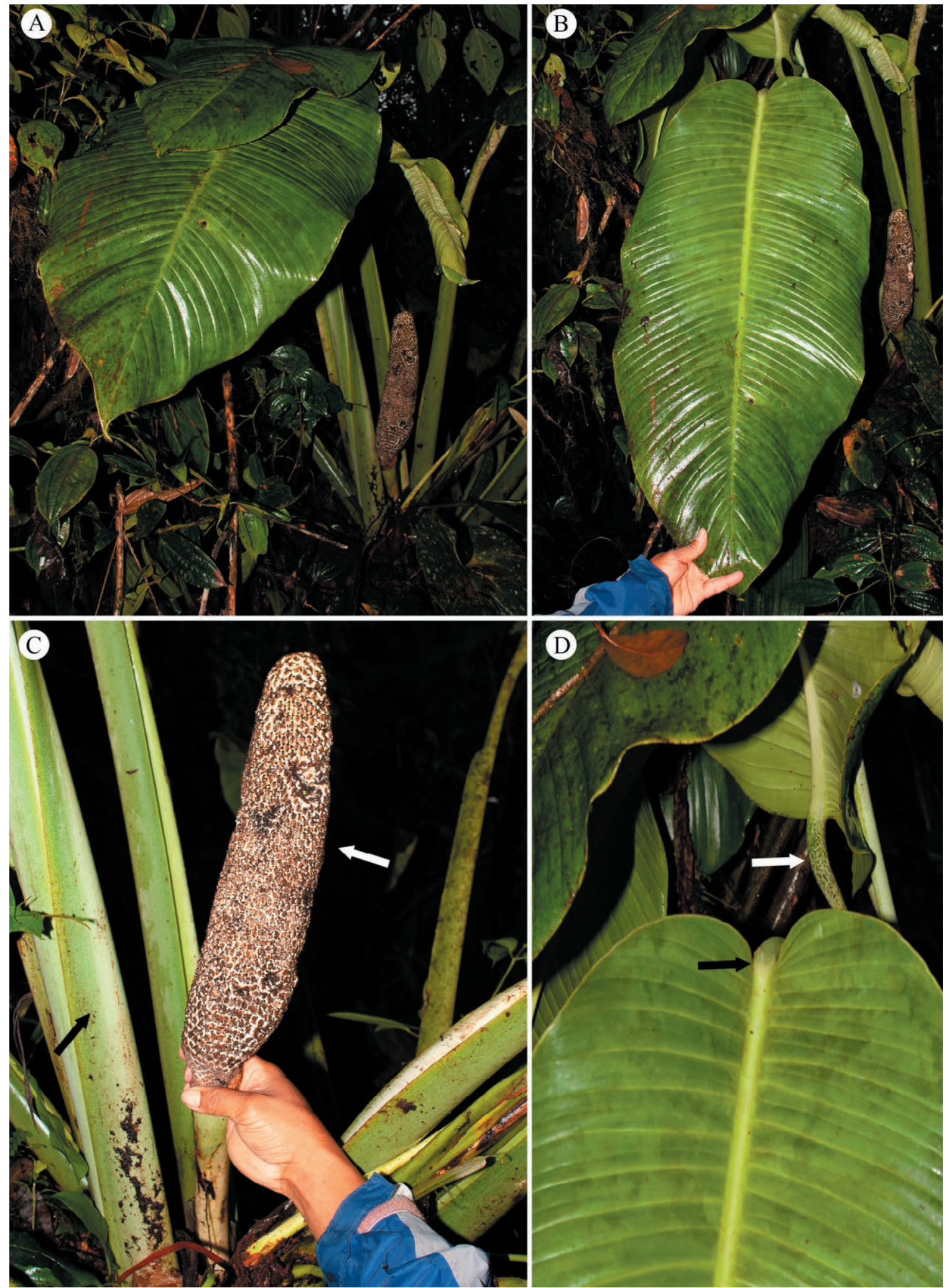

Figure 5. Monstera gigas. A. Adult plant. B. Adult leaf-blade. C. Petiole (with black arrow indicating slightly persistent sheath) and immature infructescence (with white arrow indicating white stylar cap). D. Adult leaves (with white arrow indicating white-dotted geniculum and black arrow indicating subcordate base of blade). Photos by Alejandro Zuluaga. 


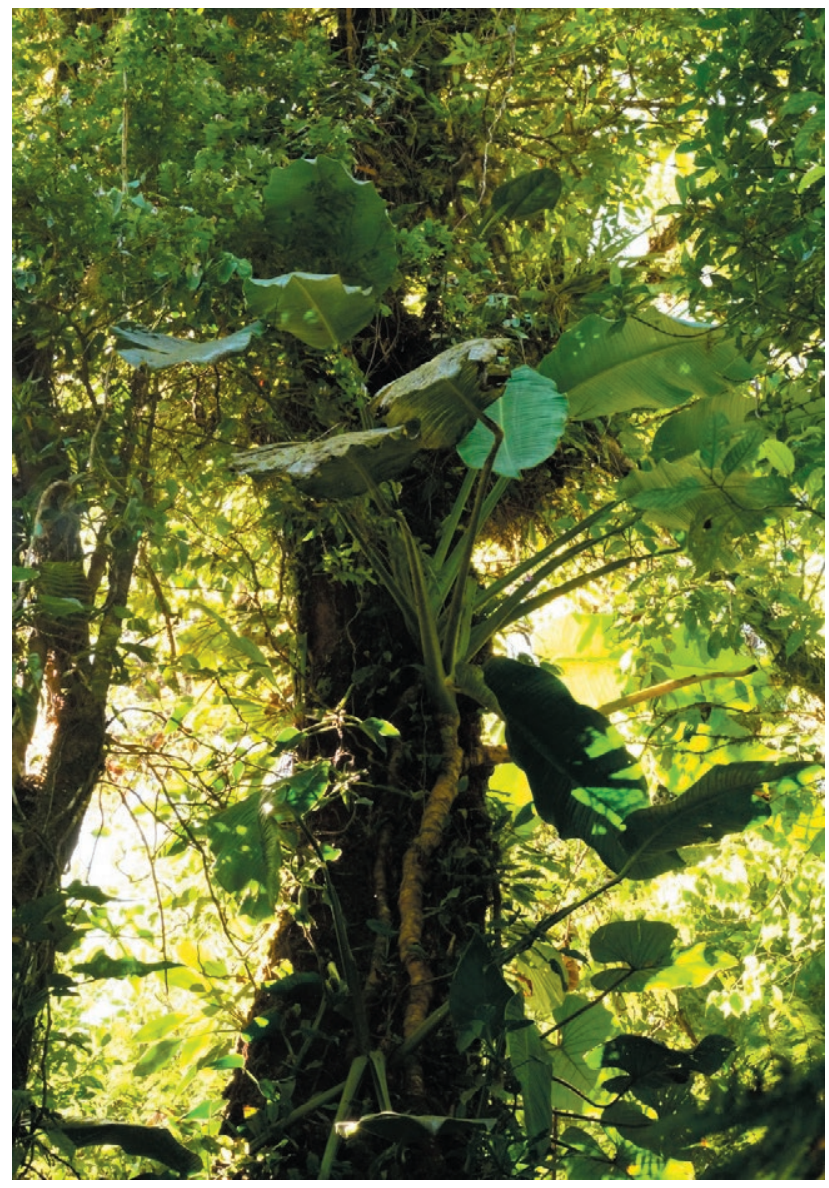

Figure 6. Monstera gigas. Adult plant with the stem beige, $11 \mathrm{~cm}$ diam, and leaves up to $3 \mathrm{~m}$ of length. Photos by Marco Cedeño.

\section{Etymology}

The epithet is a noun in apposition, from the ancient Greek word "gígas" meaning a giant, in reference to the exceedingly large size of its leaves, the largest recorded in the genus.

\section{Distribution and habitat}

Monstera gigas is endemic to Panama, where it is known only from the type locality in the region of the Fortuna Lake at $1200-1300 \mathrm{~m}$, in the Premontane rain forest life zone.

\section{Phenology}

Fruiting has been recorded in January, April, July, and September.

\section{Conservation status}

Monstera gigas should be considered as data deficient (DD).

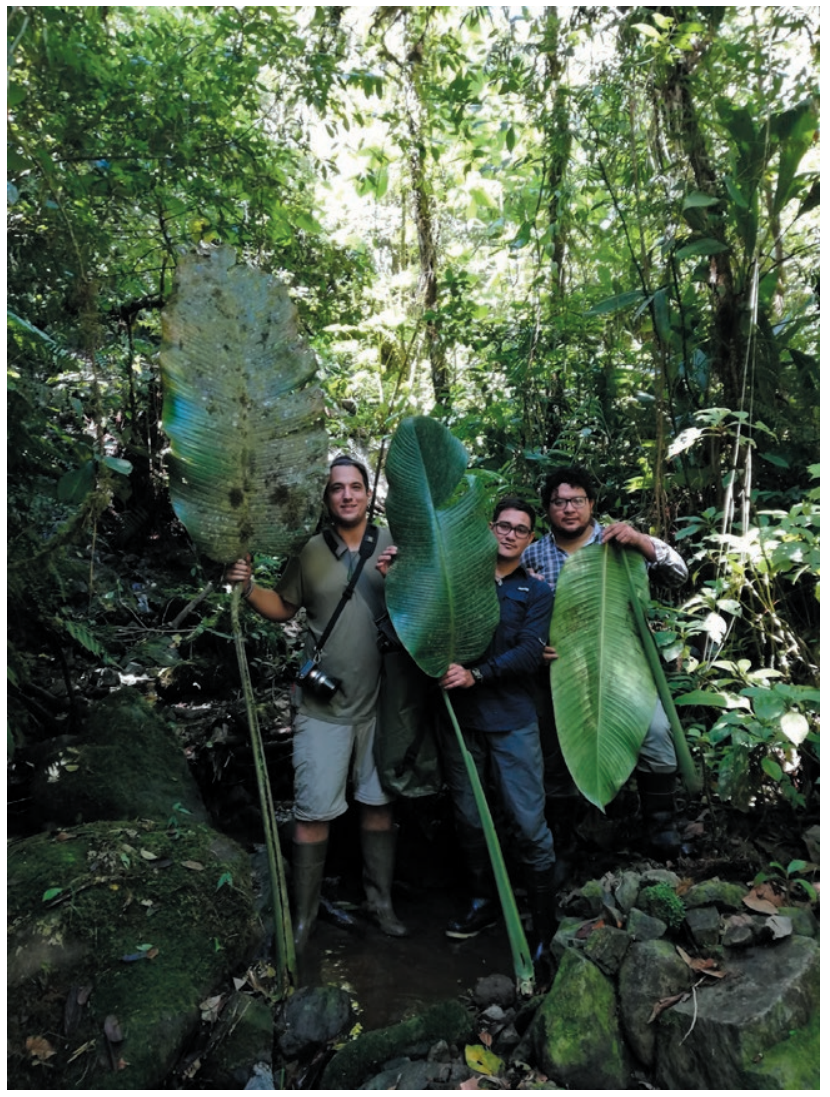

Figure 7. Monstera gigas. Michael Mittermeier (left) with a leaf up to $3 \mathrm{~m}$ of length, and Marco Cedeño and Orlando Ortiz (right) with a leaf up to $2 \mathrm{~m}$ of length. Photos by Esteban Jiménez.

Notes

This species is characterized by its usually nomadic-vine (but sometimes terrestrial) habit (but sometimes terrestrial), large stems with short, stout internodes, subterete, pale yellowish brown petioles sheathed to within 13-17 cm from the base (to $36 \mathrm{~cm}$ on preadult leaves), and ovate-elliptic, grayish-drying, entire and non-perforated, short-acuminate leaf-blades, rounded at the base and with 24-65 primary lateral veins per side, as well as by its moderately short-pedunculate, massive, green-white spathes, green spadices, and flowers with a narrow style covered for nearly its entire width by the stigma, the latter bearing a tubular extension that protrudes beyond the end of its center. Leaves at the upper end of the size range for this species, exceeding $3 \mathrm{~m}$ in length, are the largest so far know in the genus, and the plant is perhaps the most massively constructed member of its entire subfamily. Monstera gigas was first collected by last author as sterile material in April 1980, and was assumed at the time to be a new species. Later the same year it was found fertile by Thomas Antonio. Because 
of its large, entire leaves, it later became confused with M. standleyana G.S.Bunting (Bunting 1967), to which it is most probably closely related; however, the latter species differs in having fully sheathed petioles and dark brown-drying leaf-blades, rounded or acute at the base, with the basal veins arising at more acute angles and with short, pale lineations (as least on the upper surface), as well as by its flowers with a broader style and an oval stigma lacking a tubular extension.

One collection, Churchill 5508 (the holotype), was described as being terrestrial, making it exceptional for Monstera gigas; however, it may have ended up accidentally in that situation. The inflorescence of the same collection was reported to have harbored Dynastinae scarab beetles.

\section{Additional specimens examined (paratypes)}

PANAMA: Chiriquí, Vicinity of Gualaca, ca. 8.6 mi from Planos de Hornito on the road to the La Fortuna dam site, $4000 \mathrm{ft}$, Antonio 5002 (MO); Along road between Gualaca and Fortuna dam site; 7.9 mi beyond (NW) of Los Planes de Hornito; virgin forest, 1300 m, Croat 49904 (MO); Gualaca-Chiriquí Grande, 4.8 mi beyond IRHE facilities at Dam, 4 mile $\mathrm{N}$ of bridge over Bayano Lake, along gravel road which turns off main highway, $100 \mathrm{~m}$ beyond pipeline marker 108, Croat 68031 (MO); Chiriquí, Gualaca, Hornito. Fortuna, camino a Chiriquí Grande, $1230 \mathrm{~m}$, Cedeño et al. 2328 (MO, PAM, USJ). Veraguas, Vicinity of Santa Fe on slopes of Cerro Tute-Arizona above school at Alto Piedras; on trail to summit, 900-1100 m, McPherson $13672(\mathrm{MO})$.

Monstera titanum Croat, M.Cedeño \& O.Ortiz, sp. nov. (Figure 8, 9, 10)

Type: Panama. Panamá, Antón, El Valle. Valle de Antón, camino a Altos del María, 1030 m, 26 Marz 2021, M.Cedeño, O. Ortíz, J.E.Jiménez \& M.Mittermeier 2385 (holotype, PMA!; isotype, USJ!, MO!).

\section{Diagnosis}

Monstera titanum is characterized by its dark green stems with white dots, petioles 50-95 cm long, with the sheath slightly persistent, leaf blades subcordate at the base, with 20-40 primary lateral veins per side, departing the midrib at $75-95^{\circ}$, prominent collective veins, and compound fenestrations, with small fenestrations along the midrib or near the margins, and its inflorescence up to $95 \mathrm{~cm}$ in length.

\section{Description}

Habit: robust terrestrial plant in walls or robust nomadic vine, appressed-climbing. Seedlings: bearing foliose leaves. Juvenile plants: root climbers; stems smooth, dark or light green, sometimes with white dots, cylindrical; internodes $5-15 \mathrm{~cm}$ long, $0.5-1 \mathrm{~cm}$ diam.; petiole distinct, dark or light green, sometimes with white dots, smooth, 10-25 cm long, sheathed to the base of the geniculum; petiole sheath slightly persistent or completely deciduous; leaf-blades with collective veins visible, obovate, subcordate to truncate at base, acuminate at apex, thinly coriaceous, $10-20 \times 8-13 \mathrm{~cm}$, not appressed to the phorophyte; fenestrations absent or present, arranged on both sides of the midrib and in a single row of small ellipsoid fenestrations, $2-2.7 \mathrm{~mm}$ long. Adult plants: root climbers; stems light or dark green, white-spotted, smooth or slightly verrucose, cylindrical; internodes 1.5-3 cm long, 2-10 cm diam.; anchor roots black; feeder roots black; petiole light green, white-spotted, smooth or verrucose at the base, 50-95 cm long, sheathed to base of the geniculum or $15 \mathrm{~cm}$ before; petiole sheath slightly persistent; geniculum smooth, sunken adaxially, convex abaxially, 2-4.5 cm long; leaf-blades narrowly ovate-elliptic, subcordate at the base, acuminate at apex, subcoriaceous to coriaceous, drying dark brown and semiglossy adaxially, greenish yellow to brown abaxially, 47-100 × 28-35 $\mathrm{cm}, 1.6-1.7$ times longer than wide, decurrent on geniculum (decurrent portion 1-2 mm wide); midrib flattened adaxially, convex abaxially, drying reddish, light brown or black on both surfaces; primary lateral veins $20-40$ per side, strongly sunken adaxially and prominent abaxially, departing midrib at $75-95^{\circ}$, drying reddish, black or light brown; secondary veins parallel and reticulate toward the margin, undulate when dry; collective veins prominent; fenestrations absent or present in two or three rows, the first row along the midrib, with small fenestrations of $0.5-$ $5.5 \times 0.5-3.5 \mathrm{~cm}$, the second and third rows near the margins, with larger fenestrations of 9-14.5 $\times 1.7-3 \mathrm{~cm}$; margins entire. Inflorescences on ascending stems, very large; peduncle smooth, 25-48 cm long; spathe acuminate, coriaceous, completely open, light green during development, creamy or white externally and white or creamy internally at anthesis, $16.5-47 \times 10-20 \mathrm{~cm}$, up to $10 \mathrm{~cm}$ longer than the spadix; spadix cream at anthesis, $18-24 \mathrm{~cm}$ long, 2.5$6 \mathrm{~cm}$ diam., 5.5-7.3 longer than wide; basal sterile flowers 4-5 mm long; fertile flowers 7-9 $\mathrm{mm}$ long; stamens with laminar filaments 2-9 $\mathrm{mm}$ long; anthers $2-3 \mathrm{~mm}$ long; ovary rectangular in longitudinal section, ribbed , 5-6 $\times 2-3 \mathrm{~mm}$; style pyramidal, distally cylindrical, $4-5 \times$ $2.5-3 \mathrm{~mm}$; stigma linear; berries with a creamy stylar cap during development, ripe berries color unknown; seeds unknown. 


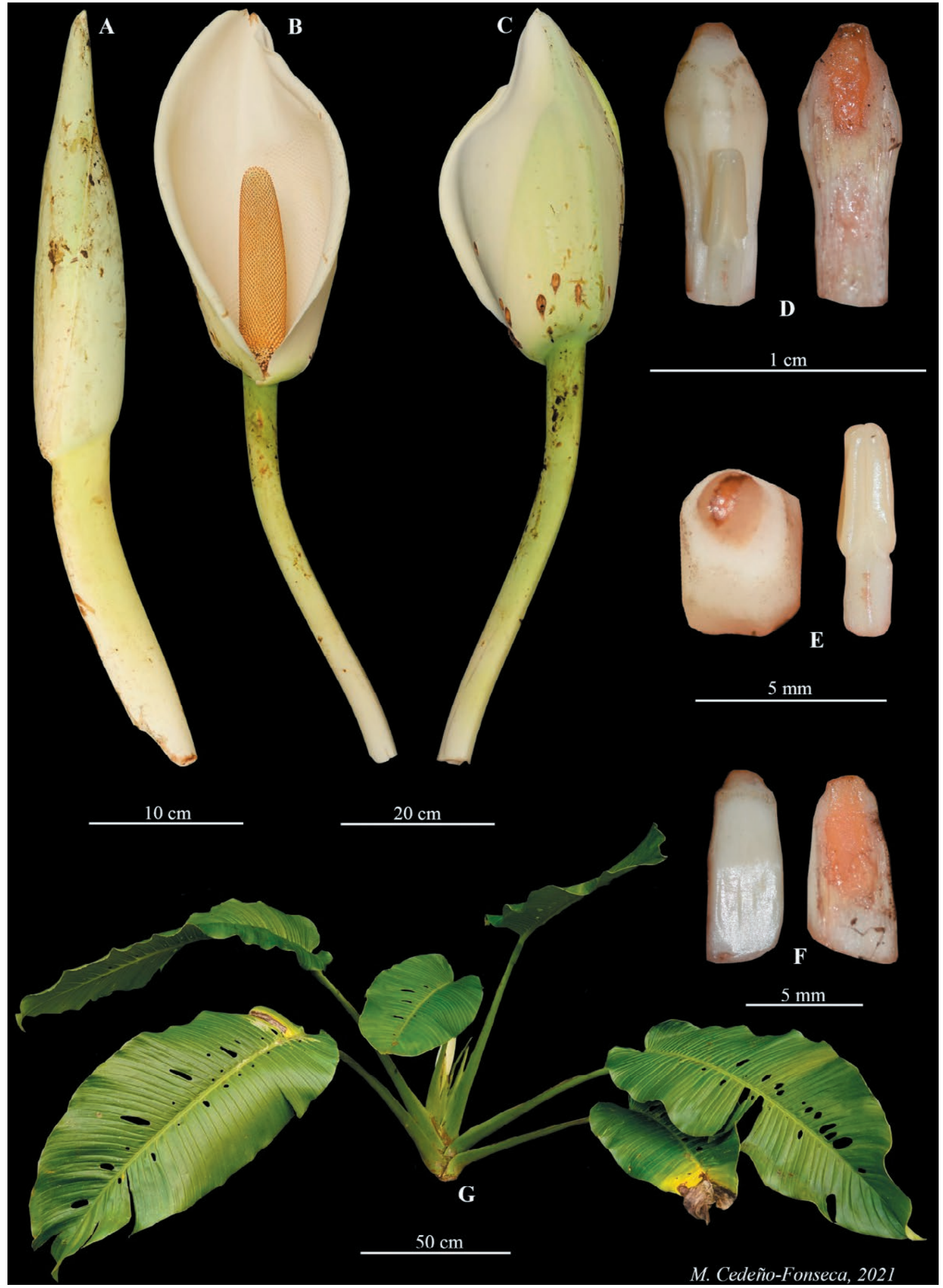

Figure 8. Monstera titanum. A. Developing inflorescence. B \& C. Front and back views of open inflorescence. D. Fertile flower in lateral view (left) and longitudinal section (right). E. Stylar plate, top view (left), and individual stamen (right). F. Sterile flower in lateral view (left) and longitudinal section (right). G. Adult plant. Photos by Marco Cedeño-Fonseca (M. Cedeño et al. 2385). 

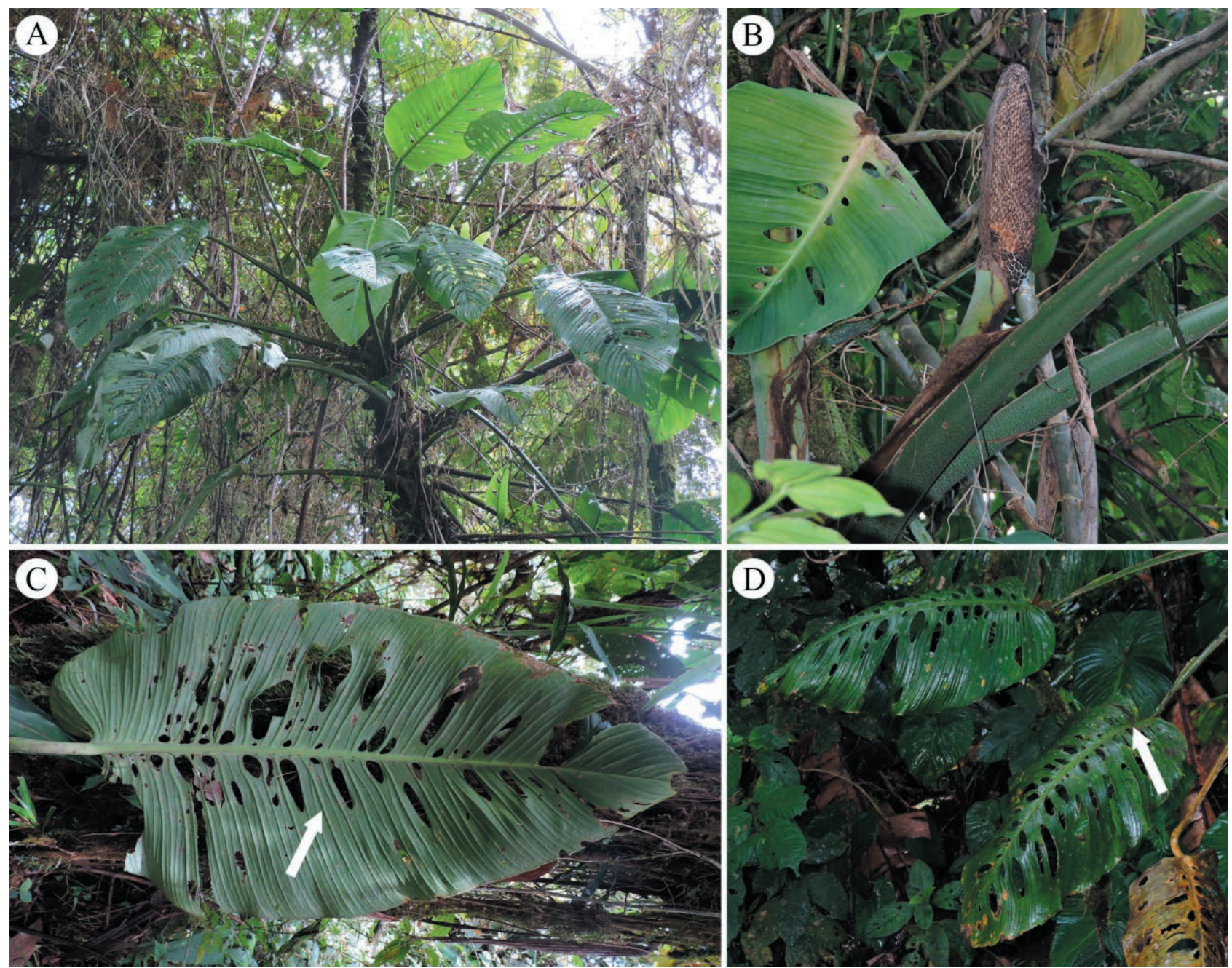

Figure 9. Monstera titanum. A. Adult plant. B. Immature infructescence, with marcescent spathe. C. Adult leaf-blade (with arrow indicating primary lateral veins departing the midrib at $75-95^{\circ}$ ). D. Adult leaf-blades (with arrow indicating subcordate base). Photos by Marco Cedeño-Fonseca.

\section{Etymology}

The species epithet, conveying enormous size, is from the greek 'titanikos' itself drawn from the Titans, the race of giant ancient Greek gods. It alludes to the huge size of the inflorescence, the largest known in the genus.

\section{Distribution and habitat}

Monstera titanum is endemic to Panama, where it is known from the type locality on Altos del Maria, Valle of Anton, and the border of Chiriquí and Bocas del Toro Provinces, at 1450-1480 m elevation in the Premontane rain forest life zone.

\section{Phenology}

Flowering has been recorded in January, March and July, and fruiting in March and November.

\section{Conservation status}

Monstera titanum should be considered as data deficient (DD).

Notes

This species is characterized by its juvenile plants with narrowly ovate, often perforated leaves and adult plants growing as nomadic vines with an appressedclimbing habit, stems with short internodes, densely speckled, fully sheathed petioles with a sharply sulcate geniculum, large, narrowly ovate-elliptic, subcordate leaf-blades with two rows of small elliptic fenestrations on both sides and drying pale greenish yellow-brown on the lower surface. The inflorescence is remarkable for its extraordinary size, with the peduncle and whitish, long- 


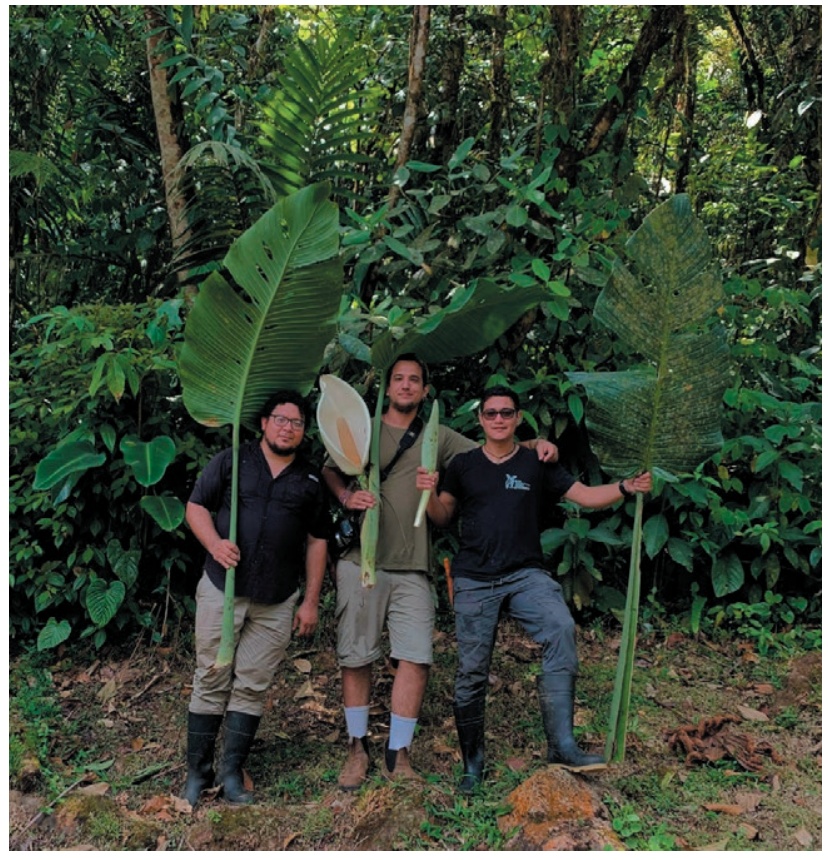

Figure 10. Monstera titanum. Orlando Ortiz (left) with a leaf up to $1.90 \mathrm{~m}$ of length, Michael Mittermeier (center) with a inflorescence up to $95 \mathrm{~cm}$ of length, and Marco Cedeño (right) with a leaf up to $2.50 \mathrm{~m}$ of length. Photos by Esteban Jiménez.

acuminate spathe each up to almost half a meter long in very robust individuals. The spadix was often found eaten by beetles but with the spathe still intact. This is unusual as typically the spathes are much more ephemeral than the spadices. Monstera titanum is similar to $M$. alfaroi Croat \& M.Cedeño ( Cedeño et al., 2020e), but differs in having smooth, light green and white-spotted petioles (vs. black-warty, light green and light brown petioles), cordate leaf-blades (vs. rounded at base), and smooth (vs. warty) peduncles.

\section{Additional specimens examined (paratypes)}

PANAMA: Bocas del Toro, Cerro Colorado, 9.2 miles $\mathrm{W}$ of Chamé; along trail $\mathrm{E}$ of road which leads down to stream, 1450-1480 m, Croat 69033 (MO); Cerro Colorado, along road between Río San Felix and mining exploration camp, $7 \mathrm{mi} \mathrm{W}$ of Chamé, along trail through Guaymí village, $1500 \mathrm{~m}$, Croat 69190 (MO); Bocas del Toro-Chiriquí border, Fortuna Dam region, along continental divide trail, $1200 \mathrm{~m}$, McPherson 13548 (G, MO, NY). Chiriquí, Cerro Colorado, along mining road, 31.6 $\mathrm{km}$ beyond bridge over Río San Félix (10.6 km beyond turnoff to Escopeta), 1690 m, Croat 37178 (MO); Fortuna, Hornito, Along the road to the Fortuna Dam site, N of Gualaca, $22.7 \mathrm{mi}$ beyond the bridge over the Río Estí, $11.8 \mathrm{mi} \mathrm{N}$ of Los Planes de Hornito, $10.7 \mathrm{mi} \mathrm{N}$ of jct. to tunnel, $1400 \mathrm{~m}$, Croat 48691 (MO); Along road between Fortuna Lake and Chiriquí Grande; $4.5-5 \mathrm{~km} \mathrm{~N}$ of dam over Fortuna Lake, 1100-1135 m, Croat 60003 (MO); Cerro Colorado, along road to old copper mine development $\mathrm{N}$ of San Félix, $18.6 \mathrm{mi} \mathrm{N}$ of bridge over river near San Félix, $6.6 \mathrm{mi}$ beyond Chamé and road to Escopeta, 1475-1485 m, Croat 75008 (MO); Cerro Colorado, along road to copper mine development $\mathrm{N}$ of San Félix, 20.5 mi $\mathrm{N}$ of the bridge near San Félix, $8.3 \mathrm{mi}$ beyond Chamé and turnoff to Escopeta, $1630 \mathrm{~m}$, Croat 75026 (MO); Gualaca, Reserva Forestal Fortuna. División Continental, 1154 m, Ortiz et al. 1809 (PMA, MO); Gualaca, Corregimiento Hornito, Reserva Forestal Fortuna, senderos cerca al centro de investigaciones Jorge L. Arauz, 12001500 m, Zuluaga 914 (PMA, MO, WIS); Ngäbe-Buglé (Bocas del Toro): Cerro Colorado, $9.2 \mathrm{mi} \mathrm{W}$ of Chamé, along trail $\mathrm{E}$ of road which leads down to a stream, 1450-1480 m, 6 Jul 1988, T.B. Croat 69012 (MO, PMA); Chiriquí, Gualaca, Hornito. Fortuna, camino a Chiriquí Grande, 1230 m, Cedeño et al. 2329 (PAM, USJ).

\section{ACKNOWLEDGMENTS}

Marco Cedeño-Fonseca thanks the Art into Acres for their support in the project to document the Monstera genus in the Neotropics, and Organization for Tropical Studies for a Glaxo-Wellcome research grant; the Rexford Daubenmire fellowship, which supported fieldwork for the project "Taxonomy of the genus Monstera (Alismatales: Araceae) for Costa Rica"; and an Alwyn H. Gentry Fellowship from the Missouri Botanical Garden and a Mini-ARTS Fellowship from the Society of Systematic Biologists, which allowed him to study herbarium material at the Missouri Botanical Garden, the Marie Selby Botanical Gardens, and the New York Botanical Garden. Orlando O. Ortiz thanks the following institutions for sponsoring this research through either field or herbarium work: University of Panama (UP), University of Florence (Herbarium FT), Missouri Botanical Garden, Smithsonian Tropical Research Institute (STRI), Ministerio de Ambiente (MiAmbiente), and Secretariat for Science, Technology and Innovation (SENACYT). Alejandro Zuluaga thanks the Smithsonian Tropical Research Institute for hosting him during his research in Panama, allowing the use of their facilities, and helping to obtain collection permits. Michael Mittermeier, Cristina Goettsch Mittermeier and Caroline Sparks also helped in raising funds for travel through a Gofundme.com campaign. Two anonymous reviewers are thanked for their insightful suggestions that greatly improved the manuscript. 


\section{REFERENCES}

Adanson, M. 1763. Familles des Plantes. 2 Vols. Paris.

Bunting, G. S. 1966[1967]. Synopsis of Araceae of Venezuela. Baileya. 14(4): 133-141.

Cedeño-Fonseca, M. 2019. Revisión taxonómica del género Monstera (Araceae) en Costa Rica. Unpublished M.Sc. Thesis, Programa de Posgrado en Biología, Sistema de Estudios de Posgrado, Universidad de Costa Rica, San José.

Cedeño-Fonseca M, Croat TB, Zuluaga A, Mittermeier M, M.A. Blanco MA. 2020a. Two new species of Monstera (Araceae: Monsteroideae) from Costa Rica. Phytotaxa. 461(3): 185-194.

Cedeño-Fonseca, M., Díaz Jiménez P, Zuluaga A, Blanco MA. 2020b. A comparison of Monstera deliciosa and M. tacanaensis, with comments on Monstera section Tornelia (Araceae). Aroideana. 43: 32-73.

Cedeño-Fonseca, M., Hay A, Grayum MH, Blanco MA. 2020c. Two new endemic species of Monstera (Araceae: Monsteroideae: Monstereae) from Golfito in southern Costa Rica. Webbia. 75: 123-132. https:// doi.org/10.36253/jopt-8091

Cedeño-Fonseca, M., Ortiz OO, Zuluaga A, Blanco MA. 2020d. New records of Araceae for Costa Rica and Panama. Phytoneuron. 2020-39: 1-8.

Cedeño-Fonseca, M., Grayum MH, Croat TB, Blanco MA. 2020e. Three new species of Monstera (Araceae: Monsteroideae: Monstereae) from the Cordillera de Talamanca in Costa Rica, threatened by the expansion of coffee plantations. Nordic Journal of Botany. 38(12, e02970): 1-13.

Cedeño-Fonseca, M., Karremans AP, \& Ortiz OO. 2018. Monstera limitaris (Araceae), a new species from the border between Costa Rica and Panama. Phytotaxa. 376: 37-42. https://doi.org/10.11646/phytotaxa.376.1.4

Croat TB, Grayum MH. 1987. New combinations in Central American Araceae. Annals of the Missouri Botanical Garden. 74: 659-660.

Grayum MH. 1997. Nomenclatural and taxonomic notes on Costa Rican Araceae. Phytologia. 82: 30-50.

Grayum MH. 2003. Araceae. Pp. 59-200 in: Hammel BE, Grayum MH, Herrera C, Zamora N (eds.). Manual de Plantas de Costa Rica. Volumen II: Gimnospermas y Monocotiledóneas (Agavaceae-Musaceae). Monographs in Systematic Botany from the Missouri Botanical Garden. 92: 1-694.

Madison M. 1977. A revision of Monstera (Araceae). Contributions from the Gray Herbarium of Harvard University. 207: 3-100.

Mayo J, Andrade I. 2013. A morphometric and taxonomic study of Monstera (Araceae) in Bahia, Brazil. Feddes Repertorium. 124: 1-24.
Pupulin F, Bogarín D. 2004. Un escaner por amigo. Epidendrum. 24: 8-10.

Sperotto P, Acevedo-Rodríguez P, Vasconcelos TNC, Roque N. 2020. Towards a standardization of terminology of the climbing habit in plants. The Botanical Review. 86: 180-210.

Tam SM, Boyce PC, Upson TM, Barabé D, Bruneau A, Forest F, Parker JS. 2004. Intergeneric and infrafamilial phylogeny of subfamily Monsteroideae (Araceae) revealed by chloroplast trnL-F sequences. American Journal of Botany. 91: 490-498.

Thiers B. 2021 [continuously updated]. Index Herbariorum: A global directory of public herbaria and associated staff. New York Botanical Garden's Virtual Herbarium. Available from: http://sweetgum.nybg. org/science/ih/ (accessed 24 June 2020).

Zuluaga A, Llano M, Cameron K. 2019. Systematics, biogeography and morphological character evolution of the hemiepiphytic subfamily Monsteroideae (Araceae). Annals of Missouri Botanical Garden. 104: $33-48$. 